\title{
Regional aspect of gender-specific economic activity in agricultural sector
}

\author{
Yuliya Chestyunina ${ }^{1}$, Irina Trushina ${ }^{1,}$, and Elena Kuba $^{1}$ \\ ${ }^{1}$ Chelyabinsk State University, Br.Kashirinyh Str., 129, Chelyabinsk, 454001, Russia
}

\begin{abstract}
The purpose of this study is to examine the gender characteristics and structure of men's and women's economic activity. By taking the social and psychological differences between women and men into consideration, regional and state programs designed to promote sustainable development can be implemented more effectively. We conducted a study among young people in order to assess their economic activity and to identify the structure of economic activity $(n=192)$. The questionnaire of economic activity (Zabelina E.V., Chestyunina Y.V.) was employed for the study. As a result, we found that the economic activity of young people has a gender-specific structure. Men have greater economic ambitions, they seek economic independence, dominance, and profit from economic activity. Women have a more distinct behavioral component the desire to be active in daily activities. Women are as much interested in economic success as men, but not in being dominant, yet they want to have a financial "safety cushion".
\end{abstract}

\section{Introduction}

The recent transformations of both the Russian and global economies have led to major changes in the field of employment. The most important of them was the change in the number of employed people and the level of employment. These processes were not gender-neutral, which is reflected in the level and scale of the decrease in the number of employed women and their inefficient involvement in the labor market [1]. Economic changes are accompanied by increased financial literacy, which is crucial for improving economic activity [2.3], yet the gender gap in financial knowledge has been found to correlate with gender differences in economic activity [4].

The term "economic activity" is understood both in economics and sociology as an indicator of the ratio of employed and unemployed people of working age in different segments of the population, which characterizes the involvement of a person in the labor market [5-8]. Historical evidence suggests that even within the same culture, a person's gender-based social roles may have gradually transformed over time. For example, most of the middle-class women in Europe and Russia were housewives until the 1950s, and their participation in productive labor outside the home was completely excluded [9]. During the Soviet Union era, the Constitution ensured the right to equal pay for equal work, and women were typically having full-time jobs. In 1988-1989, more than $85 \%$ of women of

*Corresponding author: trushina_ia@mail.ru 
working age were employed in the Baltic countries, Belarus, Russia, and Ukraine. By 1997, women's employment had dropped substantially, and many women entered the category of the economically inactive population. https:/www.unicef-irc.org/publications/pdf/chapt2_rus.pdf The current state of the problem of gender-specific features of economic activity can be assessed by analyzing statistical data of the Federal State Statistics Service, systematized data from statistical digests of Rosstat, as well as the Territorial Authority of the Federal State Statistics Service of the Chelyabinsk region. In 2020, the economically active working-age population is only 8751353 people. During the period from 2000 to 2020, the gender composition of the employable population of the Chelyabinsk region changed from $46.6 \%$ of men and $53.4 \%$ of women to $45.8 \%$ of men and $54.2 \%$ of women https://chelstat.gks.ru/population. By assessing economic activity in terms of such indicators as the ratio of men's to women's employment; the ratio of men's to women's pay for equal work; the ratio of women's to men's wages; the ratio of men to women among lawmakers, decision-makers, managers; and the ratio of men to women among professionals, we can trace the dynamics of the level of economic activity of men and women [10]. Analysis of the impact of gender on employment in the Chelyabinsk region as of 2010 revealed that employment among men $(74.1 \%)$ is higher as compared to women $(64.7 \%)$ [11].

A number of foreign and domestic studies are devoted to the study of gender problems of economic activity as a part of the employment. Evidence proves that increased economic consciousness and economic activity contribute to solving the problem of gender inequality (McCarthy, Moon, 2018). At the same time, the increase of economic activity of women is not sufficiently supported by the legislative framework and the development of the social sphere, which makes it difficult to solve the so-called "women's issue" and leads to the emergence of negative consequences [12]. Spakulova and Chulanova emphasize the importance of increasing the competitiveness of the women's labor force and reducing women's unemployment in strategies aimed at creating more opportunities for women [10]. Vitselyarova points out that women's economic initiative clashes with social discrimination against women, which manifests itself in the spheres of labor and employment, distribution of power and property, education and culture, the spiritual and political life of society. Manifestations of gender discrimination lead to gender inequalities in the labor market and employment [13].

Gender analysis of economic activity and economic behavior, in which social and psychological differences between women and men are taken into account, is aimed at identifying the potentially different impact of regional and state programs on women and men. It is required to ensure equal results in the implementation and development of state policy measures addressing the labor rights of men and women in order to achieve the sustainable development of the region and the country.

The social and cultural profile of the region has a fairly strong impact on the economic activity of men and women. The values and stereotypes that remain fixed in the consciousness have a different impact on the development and formation of appropriate economic behavior of men and women, and their " market psychology", which is essential due to the conditions of Russia's restructuring economy [14].

Psychological understanding of the economic activity of the individual consists in its progression to the optimal position in the system of economic relations (labor, property, distribution, consumer, etc.) on the basis of its attitude to social and economic conditions and their dynamics, as well as ideas about the meaning and purpose of life, personal principles, values and prohibitions, aspirations, expectations and potential opportunities as dynamic psychological units that evolve over time [14]. Kurdyukova and Korosteleva point to economic activity as an internal program of interaction between a subject and society in the area of choosing how to use social resources. At the same time, attention is paid to those 
aspects of economic activity that are consistently included in the economic activity and behavior of the subject and are manifested in the cognitive, communicative, cognitive planes of interpersonal interaction [15].

In our study, we relied on the definition proposed by Zabelina E.V., Chestyunina Y.V. [16]. From their point of view, economic activity is a property of a subject, which manifests itself in the degree of intensity and initiation in the interaction of a person and objects of economic reality (as a consumer, entrepreneur, employee, borrower, investor, etc.), including a cognitive component (activity in the search for new information to make decisions in the economic sphere), motivational and volitional (confidence in one' own ability to handle the economic situation, internal locus of control in economy), and behavioral component (manifestation of initiative in daily economic behavior) [16].

The existing lack of psychological studies in the field of gender-specific features of economic behavior and economic activity emphasizes the relevance of this study and allows us to set the goal to identify the features of economic activity of men and women.

Based on earlier studies, we formulated the following hypotheses:

H1: There are components of economic activity that are universal, where there is no significant difference between men and women;

$\mathrm{H} 2$ : There are manifestations of economic activity that are gender-specific.

\section{Research Methodology and Sample}

In order to identify the gender-specific features of economic activity, we conducted a study with the use of the questionnaire of economic activity developed by Zabelina E.V. and Chestyunina Y.V [16]. The questionnaire presents a three-component structure of economic activity: the cognitive component (activity in the search for new information to make economic decisions), the motivational and volitional component (confidence in one's own ability to handle the economic situation, internal economic locus of control), and the behavioral component (manifestation of activity in daily economic behavior).

The sample of the study consisted of 192 young people from 18 to 35 years (average age 22.8), who live in the city of Chelyabinsk.

We used descriptive statistics (analysis of mean ranks, asymmetry, and kurtosis) for statistical processing. Intergroup comparison of scale scores was performed by means of the Mann-Whitney two-tailed test, and factor analysis (method of maximum likelihood with varimax rotation with Kaiser normalization).

\section{Results}

During the first stage of the study, we examined the economic activity of young women and men. The results of the study of women are presented in Table 1.

Table 1. Descriptive statistics of women's economic activity.

\begin{tabular}{|l|c|c|r|c|c|}
\hline & Average & \multicolumn{3}{|r|}{ Asymmetry } & \multicolumn{2}{|c|}{ Kurtosis } \\
\cline { 2 - 6 } & Statistics & Statistics & Std. Error & Statistics & Std. error \\
\hline $\begin{array}{l}\text { Willingness to improve knowledge } \\
\text { in economics }\end{array}$ & 3.1733 & .532 & .198 & -.130 & .394 \\
\hline $\begin{array}{l}\text { Bringing in new things in one's } \\
\text { activities }\end{array}$ & 5.1933 & -.382 & .198 & -.773 & .394 \\
\hline $\begin{array}{l}\text { Interest in national and world } \\
\text { economic life }\end{array}$ & 3.7933 & .221 & .198 & -.874 & .394 \\
\hline Success in financial matters & 5.5800 & -1.145 & .198 & 1.112 & .394 \\
\hline
\end{tabular}




\begin{tabular}{|l|c|c|c|c|c|}
\hline $\begin{array}{l}\text { Awareness of national and world } \\
\text { economic and financial issues }\end{array}$ & 3.4400 & .390 & .198 & -.499 & .394 \\
\hline Active participation in operations & 5.4467 & -1.154 & .198 & .856 & .394 \\
\hline $\begin{array}{l}\text { Desire to be the first to learn about } \\
\text { economic changes in the country }\end{array}$ & 2.7933 & .669 & .198 & -.166 & .394 \\
\hline $\begin{array}{l}\text { Aspiration to financial success and } \\
\text { activity }\end{array}$ & 4.8667 & -.535 & .198 & -.379 & .394 \\
\hline $\begin{array}{l}\text { Aspiration to monitor national and } \\
\text { world economic events }\end{array}$ & 3.3200 & .171 & .198 & -.726 & .394 \\
\hline Activity in financial matters & 4.5600 & -.119 & .198 & -.737 & .394 \\
\hline $\begin{array}{l}\text { Discussion of economic news with } \\
\text { acquaintances }\end{array}$ & 2.3467 & .993 & .198 & .474 & .394 \\
\hline $\begin{array}{l}\text { Active influence on situation } \\
\text { Willingness to analyse the market } \\
\text { situation }\end{array}$ & 4.2000 & -.179 & .198 & -.428 & .394 \\
\hline
\end{tabular}

Looking at the mean ranks, we can see that the economic activity of women is primarily aimed at achieving success in financial matters (5.58 \pm 0.3$)$. They enjoy bringing in changes and improvements to their activities $(5.19 \pm 1.1)$ and consider themselves as active people (5.45 \pm 0.67$)$. Young women do not consider discussion of economic news important $(2.34 \pm 0.99)$ and do not try to analyse the market situation $(2.36 \pm 1.16)$.

In order to determine the normal distribution of the feature, we performed descriptive statistics of the economic activity of men which is presented in Table 2.

Table 2. Descriptive statistics of men's economic activity.

\begin{tabular}{|l|c|c|c|c|c|}
\hline & Average & \multicolumn{3}{|r|}{ Asymmetry } & \multicolumn{2}{|c|}{ Kurtosis } \\
\cline { 2 - 6 } & Statistics & Statistics & Std. Error & Statistics & Std. error \\
\hline $\begin{array}{l}\text { Willingness to improve knowledge } \\
\text { in economics }\end{array}$ & 4.1190 & -.023 & .365 & -.882 & .717 \\
\hline $\begin{array}{l}\text { Bringing in new things in one's } \\
\text { activities }\end{array}$ & 5.2619 & -1.003 & .365 & .955 & .717 \\
\hline $\begin{array}{l}\text { Interest in national and world } \\
\text { economic life }\end{array}$ & 2.9762 & .938 & .365 & -.265 & .717 \\
\hline Success in financial matters & 5.3810 & -.596 & .365 & -.793 & .717 \\
\hline $\begin{array}{l}\text { Awareness of national and world } \\
\text { economic and financial issues }\end{array}$ & 4.1905 & -.275 & .365 & -1.306 & .717 \\
\hline Active participation in operations & 5.0952 & -.557 & .365 & -.812 & .717 \\
\hline $\begin{array}{l}\text { Desire to be the first to learn about } \\
\text { economic changes in the country }\end{array}$ & 4.1190 & -.201 & .365 & -1.214 & .717 \\
\hline $\begin{array}{l}\text { Aspiration to financial success and } \\
\text { activity }\end{array}$ & 4.9762 & -.549 & .365 & -1.004 & .717 \\
\hline $\begin{array}{l}\text { Aspiration to monitor national and } \\
\text { world economic events }\end{array}$ & 3.5238 & .335 & .365 & -1.078 & .717 \\
\hline Activity in financial matters & 3.7857 & -.254 & .365 & -.426 & .717 \\
\hline $\begin{array}{l}\text { Discussion of economic news with } \\
\text { acquaintances }\end{array}$ & 3.1429 & .254 & .365 & -.478 & .717 \\
\hline Active influence on the situation & 4.1429 & -.315 & .365 & -.137 & .717 \\
\hline $\begin{array}{l}\text { Willingness to analyse the market } \\
\text { situation }\end{array}$ & 2.9048 & .403 & .365 & -1.259 & .717 \\
\hline
\end{tabular}

Looking at the average scores, we notice that the economic activity of men is also aimed at achieving success in financial matters $(5.38 \pm 0.56)$, bringing in new things in their activities (5.26 \pm 1.03$)$, and increasing activity in their operations (5.09 \pm 0.57$)$; they also perceive themselves as active people who cannot sit around. Young men have no interest in 
national and world economic life $(2.97 \pm 0.93)$ and not eager to analyse the market situation (2.9 \pm 0.4$)$.

To test the hypothesis, we conducted a comparative analysis of the indicators of economic activity of men and women. The Mann-Whitney U-test showed significant differences in gender-specific features of economic activity in the sample. The results of the comparative analysis are presented in Table 3.

Table 3. Comparative analysis of economic activity.

\begin{tabular}{|l|c|c|c|c|}
\hline \multirow{2}{*}{} & \multicolumn{2}{|c|}{ Mean ranks } & \multirow{2}{*}{ U } & \multirow{2}{*}{$\mathrm{p}$} \\
\cline { 2 - 4 } & Men & Women & & \\
\hline Willingness to improve knowledge in economics & 119 & 89 & 2172 & 0.002 \\
\hline Bringing in new things in one's activities & 100 & 93 & 2978 & 0.580 \\
\hline Interest in national and world economic life & 74 & 102 & 4062 & 0.004 \\
\hline Success in financial matters & 90 & 98 & 3385 & 0.445 \\
\hline $\begin{array}{l}\text { Awareness of national and world economic and } \\
\text { financial issues }\end{array}$ & 113 & 91 & 2453 & 0.026 \\
\hline Active participation in operations & 90 & 98 & 3397 & 0.425 \\
\hline $\begin{array}{l}\text { Desire to be the first to learn about economic changes } \\
\text { in the country }\end{array}$ & 124 & 88 & 1976 & 0.0001 \\
\hline Aspiration to financial success and activity & 101 & 94 & 2922 & 0.476 \\
\hline $\begin{array}{l}\text { Aspiration to monitor national and world economic } \\
\text { events }\end{array}$ & 99 & 95 & 3032 & 0.706 \\
\hline Activity in financial matters & 77 & 101 & 3944 & 0.011 \\
\hline Discussion of economic news with acquaintances & 120 & 89 & 2153 & 0.001 \\
\hline Active influence on the situation & 97 & 96 & 3167 & 0.953 \\
\hline Willingness to analyse the market situation & 108 & 93 & 2658 & 0.109 \\
\hline
\end{tabular}

By analysing obtained differences, we can draw the following conclusions.

Men have a higher level of willingness to improve their knowledge in economics ( $U=$ 2172; $\mathrm{p}=0.002$ ), and they are significantly more informed about economic and financial life both in their country and around the world $(\mathrm{U}=2453$; $\mathrm{p}=0.026)$, they express the desire to be the first to learn about changes in the economic life of their country $(U=1976$; $\mathrm{p}=0.0001)$ and to discuss economic news with their acquaintances $(\mathrm{U}=2153 ; \mathrm{p}=0.001)$.

Women's economic activity is expressed to a greater extent in activity in financial matters $(\mathrm{U}=3944 ; \mathrm{p}=0.011)$. Women more often perceive themselves as a type of person who cannot sit around. They also express interest in national and world economic life $(\mathrm{U}=4,062 ; \mathrm{p}=0.004)$.

According to the results of factor analysis, the structure of economic activity in each of the studied groups has gender-specific features. The results of the factor analysis are presented in Table 4.

Table 4. Factor analysis of economic activity.

\begin{tabular}{|c|c|c|c|}
\hline \multicolumn{4}{|c|}{ Men } \\
\hline $\begin{array}{c}\text { First factor } \\
\text { Economic } \\
\text { independence }\end{array}$ & $\begin{array}{c}\text { Second factor } \\
\text { Economic dominance }\end{array}$ & $\begin{array}{c}\text { Third factor } \\
\text { Receipt of dividends }\end{array}$ & $\begin{array}{l}\text { Fourth factor } \\
\text { Economic } \\
\text { ambitions }\end{array}$ \\
\hline $\begin{array}{l}\text { (Informativeness } \\
10.13 \%) \\
\text {-Activity, rationality in } \\
\text { the banking sector } \\
(0.832) \\
\text {-Willingness to save } \\
\text { money }(0.747)\end{array}$ & $\begin{array}{l}\text { (Informativeness } \\
18.87 \%) \\
- \text {-Economic ambitions } \\
(0.787) \\
- \text { Significance of } \\
\text { financial status } \\
(0.771) \\
\end{array}$ & $\begin{array}{l}\text { (Informativeness } \\
26.32 \%) \\
\text {-Financial literacy } \\
(0.608) \\
\text {-Cognitive economic } \\
\text { activities }(0.593) \\
\text {-Real estate activities } \\
\end{array}$ & $\begin{array}{l}\text { (Informativeness } \\
31.93 \%) \\
\text { - Priority of } \\
\text { money over health } \\
(0.934) \\
\text { - Priority of } \\
\text { money over }\end{array}$ \\
\hline
\end{tabular}




\begin{tabular}{|c|c|c|c|}
\hline $\begin{array}{l}\text {-Importance of } \\
\text { independent economic } \\
\text { achievements }(0.606)\end{array}$ & $\begin{array}{l}\text {-Awareness of } \\
\text { irrational } \\
\text { consumption }(0.545) \\
\text { - Consumer activity } \\
(0.529)\end{array}$ & $\begin{array}{l}(0.490) \\
\text { - Financial optimism } \\
(0.477)\end{array}$ & $\begin{array}{l}\text { vocation }(0.533) \\
\text {-Economic } \\
\text { ambitions }(0.406)\end{array}$ \\
\hline \multicolumn{4}{|c|}{ Women } \\
\hline $\begin{array}{c}\text { First factor } \\
\text { Economic success }\end{array}$ & $\begin{array}{l}\text { Second factor } \\
\text { Safety cushion }\end{array}$ & $\begin{array}{c}\text { Third factor } \\
\text { Economic activity }\end{array}$ & \\
\hline $\begin{array}{l}\text { (Informativeness } \\
10.65 \%) \\
\text {-Economic ambitions } \\
(0.804) \\
\text {-Importance of } \\
\text { independent economic } \\
\text { achievements }(0.600) \\
\text { - Financial optimism } \\
(0.500) \\
\text { - Significance of } \\
\text { financial status }(0.439)\end{array}$ & $\begin{array}{l}\text { (Informativeness } \\
19.24 \%) \\
\text { Confidence in the } \\
\text { future thanks to } \\
\text { savings }(0.724) \\
\text { Willingness to save } \\
\text { money }(0.622) \\
\text { Customer satisfaction } \\
(0.591)\end{array}$ & $\begin{array}{l}\text { (Informativeness } \\
37.24 \%) \\
\text {-Cognitive economic } \\
\text { activities }(0.626) \\
\text { - Preference to take } \\
\text { on loans }(0.505) \\
\text {-Willingness to invest } \\
(0.477) \\
\text {-Real estate activities } \\
(0.373)\end{array}$ & \\
\hline
\end{tabular}

\section{Discussion}

The data on the structure of economic activity of men and women found by means of factor analysis reveals differences that are, in our opinion, of great importance in shaping economic behavior and financial activity.

Thus, men's economic activity has the following gender-specific features: it consists of economic independence (making independent economic decisions based on the analysis of favorable offers), high economic ambitions (priority of high income as a consequence of high economic ambitions at the expense of health and vocation), economic domination (desire for high economic status and high financial position, which is possible in an industrial, developing region) aimed at receiving dividends (willingness to understand economic issues and make long-term profits).

The findings are consistent with existing perceptions about the features of men's economic activity both in the region and the country. In the economic consciousness, a man is perceived as courageous, dominant, and active [17].

The economic activity of women has several distinctive features. Women in the region strive for economic success (independence in economic achievements and financial status, which highlights their optimistic attitudes), the ability to have a financial "safety cushion" (desire for savings, which provide confidence for the near future, especially in the face of global changes and increased uncertainty), which may be related to the desire to increase economic activity and ensure a more favorable economic situation for children.

The findings suggest that there is a similarity in the dominant areas of economic activity, which can be explained by the same age group. At the same time, there are differences in economic activity: men's group is dominated by the cognitive component of economic activity, desire to be aware of events in economic and financial life both in the country and worldwide and to learn about and discuss changes in the economic life of the country. Men have greater economic ambitions, they seek economic independence, dominance, and profit from economic activity.

Women have a more distinct behavioral component, as they strive to be active in their daily activities. On the other hand, confidence in one's own personal activity and financial success, certainty that one can influence the financial situation, active behavior demonstrating a readiness to change behavior in response to external challenges, and proactive behavior (as opposed to passive behavior) are evident among women. Both 
women and men strive for economic success, but not for domination, and there is a need for a financial "safety cushion", which is treated as a necessary fund of savings meant to be used in case of various and critical force majeure circumstances. According to the survey https://www.mk.ru/editions/daily/2020/06/18/opros.html, 60\% of Russians have a " safety cushion", and most of them do not exceed 100000 rubles. This fact agrees with the available data [18], which indicates that a safety cushion should become an integral part of any person's life, especially during a pandemic.

\section{Conclusion}

Therefore, the results of the study show that men have a more developed cognitive component (activity in the search for information to make decisions in the economic sphere) of economic activity. It is impossible to overcome difficulties without volitional decisions and motivation to act. Aspiration to self-respect, the need for economic activity, and the ability to enjoy one's activities constitute an economic activity. For men, economic activity consists of economic independence, high economic ambitions, a desire for economic domination, and a focus on profit.

For women, it is more typical to take an active role in daily economic behavior. Motivational and volitional (confidence in one's own ability to handle the economic situation, integral economic locus of control) and behavioural (manifestation of activity in daily economic behaviour) components of economic activity equally developed both for men and women. Women strive for economic success, give priority to having a financial "safety cushion", which improves economic activity and ensures a more stable economic position.

To conclude, it is necessary to mention that the identified gender-specific features of the structure of economic activity need to be taken into account when developing and implementing regional economic development programs. Under conditions of uncertainty caused by the pandemic, it is strategically important to develop the human capital that will provide the economic growth of the regions and Russia as a whole.

\section{Acknowledgments}

The research was funded by RFBR and Chelyabinsk Region, project number 20-413740019.

\section{References}

1. L.A. Kravchenko, Gender inequality in employment: the case of Primorsky Krai (Vladivostok, 2008)

2. O.S.M. Lusardi, Journal of Economic Literature 52(1) (2013) DOI: 10.2139/ssrn.2243635

3. L. McCarthy, J. Moon, Organization Studies 39(4), 017084061878735 (2018) DOI:10.1177/0170840618787358

4. Organisation for Economic Cooperation and Development. Women and financial education: Evidence, policy responses and guidance (2013) DOI: 10.1787/9789264202733-en

5. V.A. Kiseleva, Economic Activity of Women (Regional Aspect) (Maykop, 2005)

6. S.G. Fedorchukova, Bulletin of the Institute of Economics and Crisis Management 9, 10 (2015) 
7. V. P. Fominykh, A. N. Zakharova, Advances in modern natural science 3, 138 (2004)

8. V.V. Smirnov, A.N. Zakharova, G.S. Dulina, Economic analysis: theory and practice 2(497), 286-309 (2020) DOI: 10.24891/ea.19.2.286

9. E.I. Martynova, Topical issues of polychotomous analysis, 150-154 (2020)

10. L.S. Spankulova, Z.K. Chulanova, Economics: strategy and practice 3(31), 81-91 (2014)

11. S. Abramkina, Society and power 6(38), 93-99 (2012)

12. L.A. Kravchenko, Gender inequality in employment: on the example of the Primorsky Territory: abstract of the dissertation of the Candidate of sociological sciences: 22.00.04 (Southern feder. un-t, Vladivostok, 2008)

13. K.N. Vitselyarova, Business. Education. Law 4(33), 66-70 (2015)

14. A.L. Zhuravlev, A.B. Kupreichenko, Bulletin of practical educational psychology 1, 50-55 (2007)

15. N.A. Kurdyukova, T.V. Korosteleva, New in psychological and pedagogical research 2(38), 208-212 (2015)

16. E.V. Zabelina, Y.V. Chestyunina, Bulletin of the Saratov University. Philosophy Series. Psychology. Pedagogy 20(3), 307-314 (2020) DOI: 10.18500/1819-7671-202020-3-307-314

17. S.S. Rezanova, M.Y. Shahova, E.N. Makovetskaya, Materials of the international scientific and practical conference of students and postgraduates, 46-49 (2008)

18. T.S. Popova, D.S. Kalmykova, K.I. Khudoteplova, Management of socio-economic development of regions: problems and ways to solve them. Collection of articles of the 10th International Scientific and Practical Conference, 363-366 (2020) 